\title{
Can vaccines against canine visceral leishmaniasis interfere with the serological diagnostics recommended by the Brazilian Ministry of Health?
}

\author{
Monique Paiva de Campos ${ }^{1 *}$ Paula Mello De Luca ${ }^{2}$ Alinne Rangel dos Santos Renzetti ${ }^{1}$ \\ Sara Maria Marques de Souza ${ }^{1}$ Artur Augusto Velho Mendes Júnior ${ }^{1}$ \\ Renata Simões Barros ${ }^{3}$ Fabiano Borges Figueiredo $^{1}$
}

${ }^{1}$ Instituto Nacional de Infectologia Evandro Chagas (INI), Fundação Oswaldo Cruz (Fiocruz), 21045-900, Rio de Janeiro, RJ, Brasil. E-mail: m.pcampos@yahoo.com.br. "Corresponding author.

${ }^{2}$ Laboratório de Imunoparasitologia, Instituto Oswaldo Cruz (IOC), Fundação Oswaldo Cruz (Fiocruz), Rio de Janeiro, RJ, Brasil.

${ }^{3}$ Médica Veterinária do $1^{\circ}$ Batalhão de Guardas, Exército Brasileiro, Rio de Janeiro, RJ, Brasil.

ABSTRACT: The objective of the current research was to assess seroconversion in dogs immunized with Leishmune ${ }^{\mathbb{B}}$ and Leish Tec ${ }^{\mathbb{B}}$ vaccines using rapid chromatographic immunoassay DPP ${ }^{\circledR}$ (Dual Path Platform) (DPP CVL) and enzyme immunoassay (EIE) up to one year after the vaccination protocol. The study sample comprised 28 dogs divided into two groups, each group immunized with an anti-CVL vaccine and clinically monitored for one year through clinical evaluation and laboratory tests. 22 (78.5\%) dog were monitored. During the evaluation time (T1-30 days, T2-6 months, and T3-1 year after vaccination) the results for all dogs were negative for CVL, except for one animal vaccinated with Leish tec ${ }^{\circledR}$ that seroconverted in the DPP CVL test at T2. Subsequent examinations of this dog were negative. Our results showed that in a non-endemic area, even at different evaluation times, dogs vaccinated against CVL with Leishmune ${ }^{\circledR}$ or Leish tec ${ }^{\circledR}$ did not seroconvert in the serological protocol used by the Brazilian Ministry of Health (DPP/EIE).

Key words: canine visceral leishmaniasis, vaccine, diagnosis, seroconversion.

Vacinas anti-leishmaniose visceral canina podem interferir no diagnóstico sorológico preconizado pelo Ministério da Saúde brasileiro?

RESUMO: O objetivo deste trabalho foi avaliar a soroconversão em cães imunizados com as vacinas Leishmune ${ }^{\circledR}$ e Leish tec ${ }^{\circledR}$, através do teste imunocromatográfico rápido DPP ${ }^{\circledR}$ (Dual Path Platform) (DPP LVC) e do ensaio imunoenzimático (EIE) durante um ano após o protocolo vacinal. Trata-se de um estudo onde 28 cães divididos em dois grupos foram imunizados cada um com uma vacina anti - LVC e acompanhados durante um ano através de avaliação clínica e exames laboratoriais. Foi possível acompanhar 22 (78.5\%) cães. Nos exames dos tempos 1, 2 e 3 (respectivamente 30 dias, 6 messes e 1 ano após a vacinação) os resultados de todos os cães também foram negativos para LVC, exceto de um cão que recebeu a vacina Leish tec ${ }^{\circledR}$ e soroconverteu no DPP LVC no T2, após 6 meses a vacina. Os exames posteriores deste cão foram negativos. Os resultados do presente estudo demostraram que, em área não endêmica e mesmo em diferentes tempos de avaliação, cães vacinados contra LVC, independente da vacina utilizada, não foram capazes de soroconverter no protocolo utilizado pelo Ministério da Saúde brasileiro (DPP/EIE).

Palavras-chave: leishmaniose visceral canina, vacina, diagnóstico, soroconversão.

\section{INTRODUCTION}

In Brazil, canine visceral leishmaniasis $(\mathrm{CVL})$ is an infection caused by Leishmania infantum, and it has the sandfly Lutzomyia longipalpis as its main vector. In dogs, CVL occurs slowly and chronically. It presents a broad spectrum of clinical signs, or it is sometimes asymptomatic, depending on the animal's immune competence (MINISTÉRIO DA SAÚDE. 2006). Cases of canine leishmaniasis precede cases of human infection, considering that the dog plays a key role on the transmission chain of $\boldsymbol{L}$. infantum, the causative agent of CVL in Brazil (MINISTÉRIO DA SAÚDE, 2006). Dogs are the main parasite reservoir and source of infection for phlebotomine sandflies in urban areas (MINISTÉRIO DA SAÚDE, 2006).

The Brazilian Ministry of Health (MH) recommends that serological tests - DPP ${ }^{\circledR}$ (Dual Path Platform) (DPP CVL) and enzyme immunoassay (EIE) - should be conducted for the screening of dogs (NOTA TÉCNICA N ${ }^{\circ} 01 / 2011$ ), and that animals with positive results in both tests need to be euthanized as an alternative to disease treatment and a control measure (MINISTÉRIO DA SAÚDE, 2006).

Euthanasia of infected dogs, in addition to causing great social nuisance, does not seem to be effective, considering that CVL has expanded to non-endemic areas (SILVA et al., 2015). Therapeutic protocols have also been tested, but the parasitological 
cure of infected animals has not yet been reported. Some authors suggested that the development of a vaccine could be an effective measure for the control of CVL (PALATNICK-DE-SOUZA, 2008).

Two anti-CVL vaccines have been developed and commercially launched in Brazil: Leishmune $^{\circledR}$ (Zoetis $^{\circledR}$, New Jersey, USA) and Leish$\operatorname{Tec}^{\mathbb{R}}$ (Hertape Calier Saúde Animal ${ }^{\circledR}$, Minas Gerais, Brazil). However, Leishmune ${ }^{\circledR}$ had its marketing temporarily suspended by the Brazilian Ministry of Agriculture, Livestock, and Food Supply (MAPA) in 2014 because it did not completely fulfill the phase-III requirements of the vaccine efficacy assessment trial (MAPA, NOTA TÉCNICA 038/2014). Therefore, Leish-Tec $^{\circledR}$ (Hertape Calier Saúde Animal ${ }^{\circledR}$, Minas Gerais, Brazil) is currently the only commercially available anti-CVL vaccine in Brazil.

Such vaccines had their marketing approved by the MAPA; nevertheless, the MH does not recommend their use for public health purposes, considering that the main screening and confirmatory tests (DPP CVL and EIE) are serological, which allows the possibility of the humoral immune response elicited by the vaccines interfere with the diagnosis, in addition to the inability to distinguish vaccinated animals from infected animals in the serological tests recommended by the MH (NOTA TÉCNICA MINISTERIO DA SAÚDE, 2005). Furthermore, studies to assess the impact of the use of these vaccines for public health purposes are still being conducted (NOTA TÉCNICA INTERMINISTERIAL, 2009).

In view of the complex scenario for CVL control, it is necessary to investigate other control methods be in order to avoid disease expansion and eventually lead to a decrease in the number of cases. The objective of the present study was to evaluate seroconversion in dogs immunized with the Leishmune ${ }^{\circledR}$ and Leish-Tec ${ }^{\circledR}$ vaccines using the DPP ${ }^{\circledR}$ (Dual Path Platform) (DPP CVL) rapid immunochromatographic assay and the (EIE) enzyme immunoassay for one year after the immunization protocol.

\section{MATERIALS AND METHODS}

This is a cohort study conducted with 28 dogs from two kennels of the Brazilian Army. Dogs were submitted to collection of clinical specimens for diagnosis, vaccination against $\mathrm{CVL}$, and assessment of seroconversion using the serological tests for diagnosis of CVL recommended by the Brazilian Ministry of Health (NOTA TÉCNICA no. 01/2011).

Dogs surveyed were of defined breeds (German Shepherd, Belgian Malinois, Labrador,
Rottweiler, and American Staffordshire Terrier), with known history and high genetic value. They dwell in individual pens, received balanced nutrition, and are regularly vaccinated against the main canine infections and vermifuged. These dogs are physically trained daily for their roles in the army (patrolling, personnel policing, guarding of military installations, detection of narcotics and explosives, and use in operations of preservation of law and order).

After being clinically examined and testing negative in the DPP ${ }^{\circledR}$ (Dual Path Platform - DPP LVC) assay, the dogs were immunized. Sixteen dogs from kennel no. 1 were immunized with the Leish$\operatorname{Tec}^{\circledR}$ (Hertape Calier Saúde Animal ${ }^{\circledR}$, Minas Gerais, Brazil) vaccine and twelve dogs from kennel no. 2 were immunized with the Leishmune ${ }^{\circledR}$ (Zoetis $^{\circledR}$, New Jersey, USA) vaccine, following the immunization protocol recommended by the manufacturers ( 3 doses with an interval of 21 days in dogs aged four months or older). The vaccines were purchased independently from suppliers with money from the funding agencies that supported the research.

Vaccines assessed in this study used different antigens to induce the immune response: Leishmune ${ }^{\circledR}$ is an inactivated vaccine whose immunogen is the fucosemannose ligand (FML) glycoprotein from promastigote forms of Leishmania donovani associated with a saponin-based adjuvant, whereas Leish-Tec ${ }^{\circledR}$ (Hertape Calier Saúde Animal) uses a recombinant amastigotestage-specific protein, named A2 antigen, present in different Leishmania species, and is able to induce potent type 1 response (RESENDE et al., 2008).

These dogs were monitored for one year after the immunization protocol - Time 0: clinical examination; collection of samples (blood and bone marrow) for testing and beginning of the vaccination protocol $\left(1^{\text {st }}, 2^{\text {nd }}\right.$ and $3^{\text {rd }}$ doses of the vaccine with an interval of 21 days). Time 1 ( 30 days after the $3^{\text {rd }}$ dose of vaccine): clinical examination; collection of samples (blood) for further testing. Time 2 (6 months after the $3^{\text {rd }}$ dose of vaccine): clinical examination; collection of samples (blood) for further testing. Time 3 (1 year after the $3^{\text {rd }}$ dose of vaccine): clinical examination; collection of samples (blood) for further testing.

For evaluation of possible adverse reactions related to the vaccine, animals were monitored by veterinarians for up to 48 hours after each immunization. The following adverse reactions could occur according to the inserts of the vaccines: transient pain, inflammation and alopecia at the application site, lethargy or anorexia and, in rare instances, allergic or anaphylactic reactions.

The following techniques were utilized as reference standards: DPP ${ }^{\circledR}$ (Dual Path Platform - 
DPP LVC), quantitative polymerase chain reaction (qPCR), and parasitological culture. Animals that tested negative in the three techniques used were considered seronegative (healthy), whereas animals that tested positive in at least one of the techniques used were considered seropositive. Only animals considered negative for CVL were included in the survey. Animals older than 8 years and younger than 9 months, pregnant females, and ill dogs were also excluded from the study.

DPP CVL was used for diagnosis at time 0 and as seroconversion control after vaccination at times 1, 2, and 3. Volumes of blood or serum without anticoagulant of approximately $5 \mu \mathrm{L}$ were used according to the manufacturer's recommendations. The test was considered positive when the two tracks, referring to the test sample and the control, were visible.

For the search of anti-Leishmania specific antibodies, we used the EIE-leishmaniasis (Biomanguinhos/Fiocurz, Brazil) (EIE-CL) kit, which utilizes Leishmania major-like (MHOM/ $\mathrm{BR} / 76 / \mathrm{JOF}$ ) promastigote forms produced by Biomanguinhos/Fiocruz as antigen. This exam was used as a confirmatory test in the cases where positive results were obtained in the DPP at any of the examination times, as recommended by the $\mathrm{MH}$.

Polymerase chain reaction (qPCR) and parasitological culture were performed with the bone marrow aspirate of the animals; these techniques were utilized as reference standards at time 0 . The protocol for bone marrow and blood collections and the procedure for parasitological culture were conducted as previously described by ABRANTES et al. (2016).

To conduct qPCR and extraction and purification of DNA from bone marrow, a DNeasy ${ }^{\mathbb{R}}$ Blood \& Tissue (Qiagen ${ }^{\circledR}$, California, USA) kit was used in a Qiacube (Qiagen ${ }^{\circledR}$, California, USA) semiautomated platform for extraction of nucleic acids following the manufacturers' instructions.

When mounting the reaction plate for running DNA amplification and quantification, 10-fold serial dilutions were performed on samples of DNA extracted from promastigote forms of $\boldsymbol{L}$. chagasi (MHOM/ BR/1974/PP75) (sin. L. infantum) used in the standard curve for determination of genomic copy number.

Samples were amplified using a StepOne ${ }^{\mathrm{TM}}$ (Thermo Fisher Scientific ${ }^{\circledR}$, Basingstoke, UK) platform; each sample was amplified in triplicate. The hydrolysis probe (TaqMan ${ }^{\circledR}$ MGB, Thermo Fisher Scientific ${ }^{\circledR}$, Basingstoke, UK) and PCR primers were designed to target conserved DNA regions of the kinetoplast minicircle DNA (kDNA) from $\boldsymbol{L}$. infantum, as well as the sequencing method, were previously described in the protocol by FRANCINO et al. (2006).

Positive and negative controls were used in the amplification and a threshold of 0.1 was established for all samples from the point at which the emitted fluorescence exceeded the limit considered negative. The limit to obtain the detectable results was established at 37 cycles. Samples amplified after cycle 37 were considered undetectable. This test was used for diagnosis at time 0 and as seroconversion control when the DPP CVL was positive in any of the dogs monitored in the study.

To serve as positive control, a group of 10 dogs naturally infected with $\boldsymbol{L}$. infantum from the endemic area of Barra Mansa, Rio de Janeiro State, were included in the study. Screening was conducted using the tests recommended by the MH. After the clinical examination and sedation of animals, blood samples were collected to perform the DPP CVL and EIE tests and bone marrow samples were collected to perform the reference standard tests following the same methodology used in the immunized animals. After these procedures, dogs were euthanized at the Laboratório de Pesquisa Clínica em Dermatozoonoses - INI/Fiocruz according to the MH recommendation for seropositive animals, using overdose of intravenous sodium thiopental until cardiorespiratory functions are disrupted and death is confirmed.

\section{RESULTS}

Monitoring was interrupted in six of the 28 dogs vaccinated; consequently, the study sample was composed of 22 animals (78.5\%). Twelve $(54.5 \%)$ dogs from kennel no. 1 were immunized with Leish-Tec ${ }^{\circledR}$ and $10(45.4 \%)$ dogs from kennel no. 2 were immunized with Leishmune ${ }^{\circledR}$. Mean age was 34.2 months (11 to 66 months) for kennel no. 1 and 34.5 months (9 to 96 months) for kennel no. 2. Mean weight was $29.2 \mathrm{~kg}$ (18 to $50 \mathrm{~kg}$ ) for kennel no. 1 and $29.8 \mathrm{~kg}$ (20 to $42.3 \mathrm{~kg}$ ) for kennel no. 2. All of the dogs surveyed presented good general health status. No adverse reactions were observed after immunization upon animal supervision.

Of the 10 naturally infected dogs, seven $(70 \%)$ were male and three $(30 \%)$ were female. There were eight $(80 \%)$ mongrels, one $(10 \%)$ Poodle, and one (10\%) Dachshund. One dog (10\%) was asymptomatic, with no clinical signs, and nine were $(90 \%)$ symptomatic. None of the animals were castrated; mean age was 67.6 months (24 to 192 months); mean weight was 10 kilograms (5 to $15 \mathrm{~kg}$ ).

All vaccinated dogs also showed negative results for CVL in the examinations at Times 1,2 and 
3, except for one dog that was immunized with Leish$\mathrm{Tec}^{\circledR}$ and seroconverted in the DPP CVL at Time 2 six months after vaccination. Bone marrow and blood collections were conducted again in this dog and the results in the parasitological culture, qPCR, and EIE were negative. After one year (Time 3), this dog tested negative in the DPP CVL.

All naturally infected dogs had positive in DPP CVL, EIE, parasitological culture and qPCR.

\section{DISCUSSION}

The first license granted by the Brazilian Ministry of Agriculture, Livestock, and Food Supply (MAPA) for the commercialization of anti-canine visceral leishmaniasis vaccine occurred in 2003 Leishmune $^{\circledR}$ (Zoetis). In 2005, the Brazilian Ministry of Health $(\mathrm{MH})$ published a technical note listing several aspects, including the possible seroconversion of vaccinated dogs, reported in tests recommended for this purpose, which hindered the diagnosis and removal of truly positive animals from endemic areas. In 2008, another vaccine was launched in the market - Leish-Tec ${ }^{\circledR}$ (Hertape Calier Saúde Animal); however, it presented the same flaw.

After immunization and throughout the development of the immune response, the organism can develop some adverse reactions. In our study, no adverse reactions were observed in the immunized dogs, probably due to the good immunological status and/or because the dogs were of medium to large breeds, considering that dogs of small breeds are more sensitive to pain in the application site. TESTASICCA et al. (2014) also did not observe significant adverse reactions in animals immunized with Leish-Tec ${ }^{\circledR}$. FERNANDES et al. (2015) reported adverse reactions in one dog vaccinated with Leishmune ${ }^{\circledR}$ and in six dogs immunized with Leish-Tec ${ }^{\circledR}$; these dogs were of varied breeds, genders, and ages, from an endemic area.

A specific immune response to vaccination antigens is of great importance, but it should not cause seroconversion in the serological tests used by the $\mathrm{MH}$ for the diagnosis of CVL. Even with the low specificity of the serological tests used (EIE and IFAT) owing to possible cross-reactions with other trypanosomatids (MADEIRA et al., 2009), their use in epidemiological studies and surveys on CVL control measures is essential because of the ease to obtain samples and their low costs (ALMEIDA et al., 2005).

In studies conducted by the manufacturers of the Leish-Tec ${ }^{\circledR}$ and Leishmune ${ }^{\circledR}$ vaccines using the EIE technique for the detection of humoral response to homologous proteins (A2 and FML, respectively),
TESTASICCA et al. (2014) reported positivity of $98 \%$ in animals immunized with Leish-Tec ${ }^{\circledR}$; this value decreased to $81 \%$ after six months, and returned to $98 \%$ two months after the boosting vaccine dose (14 months after the priming vaccination). Similarly, NOGUEIRA (2005) observed seropositivity of $100 \%$ in dogs immunized with Leishmune ${ }^{\circledR}$ for up to 11 months. With respect to the positivity assessment of the tests used by the $\mathrm{MH}$, seroconversion in dogs vaccinated with Leishmune ${ }^{\circledR}$ was reported in DPP and EIE 6 months after the vaccination protocol (MARCONDES et al., 2013). In contrast, dogs immunized with Leish$\mathrm{Tec}^{\circledR}$, monitored up to 14 months after the priming vaccination, did not present seroconversion in the $\mathrm{MH}$ tests (TESTASICCA et al., 2014).

In a similar study, but conducted with animals from an endemic region monitored for one month after vaccination, 22 dogs were immunized with Leishmune $^{\circledR}$ and 22 with Leish-Tec ${ }^{\circledR}$. None of the dogs vaccinated with Leish-Tec ${ }^{\circledR}$ seroconverted in the DPP CVL and 9\% seroconverted in the EIE, whereas $9 \%$ of the dogs immunized with Leishmnune ${ }^{\circledR}$ seroconverted in the DPP CVL, 73\% seroconverted in the EIE, and 9\% presented inconclusive results (SOLCÀ et al., 2013).

In this survey, $21(95.4 \%)$ dogs did not seroconvert at the three monitoring times when DPP CVL was used as the screening test and EIE was used as the confirmatory test. One animal seroconverted in the DPP CVL six months after the vaccination protocol with Leish-Tec $^{\circledR}$, but negative results were reported in the confirmatory tests (EIE and parasitological culture). After a year, the same dog tested negative in the DPP CVL.

Although both vaccines tested use purified antigens or recombinant DNA molecules different from those that compose the DPP CVL and EIE, false positive cases may occur due to cross-reactivity with other pathogenic trypanosomatids in serological tests (ALVES et al., 2012). Previous studies have shown higher levels of seroconversion to the $\mathrm{MH}$ tests (SOLCÀ et al. 2013; MARCONDES et al., 2013); however, the highest seroconversion rate has always been verified in the EIE, formulated with complete L. major antigen promastigotes, presenting low concentrations of vaccine antigens, which would justify these findings.

In contrast, the DPP seroconversion rate has always been very low in these studies, which corroborates our results. As DPP utilizes a recombinant antigen different from those that compose both vaccines, this positivity could occur owing to cross-reaction with other trypanosomatids or a natural Leishmania infection in connection with 
a possible flaw in the immunity induction by the vaccine (TESTASICCA et al., 2014). As the main objective of this study was to assess whether both vaccines would be able to induce an erroneous CVL diagnosis using the diagnostic protocol recommended by the MH, only dogs with positive results in the DPP were also tested in the EIE.

Studies show that the sensitivity and specificity of the DPP CVL technique may reach $87.5 \%$ and $73.3 \%$, respectively (SCHUBACH et al., 2014), and that significant improvement in the diagnostics of CVL has been observed since the new protocol (DPP CVL and EIE) was implemented (SCHUBACH et al., 2014). Our study demonstrated that the methodology using DPP CVL and EIE, is sensitive, specific, and able to separate truly positive dogs from those immunized for CVL.

\section{CONCLUSION}

Results of this study demonstrated that, even at different assessment times, dogs vaccinated against canine visceral leishmaniasis, regardless of the vaccine used, were not able to seroconvert under the protocol used by the Brazilian Ministry of Health (DPP/EIE); therefore, no dog would have been mistakenly euthanized in the population investigated.

\section{ACKNOWLEDGEMENTS}

The authors are grateful to $1^{\circ}$ Batalhão de Guardas, $1^{\circ}$ Batalhão de Polícia do Exército, and Lieutenant Alex Canto de Oliveira for the support provided to the conduction of this study. We acknowledge the Programa de Pós-graduação de Pesquisa Clínica em Doenças Infecciosas - INI/Fiocruz for the doctoral fellowship. We are also grateful to Dr. Valmir Laurentino Silva and the Departamento de Ciências Biológicas da ENSP-Fiocruz.

This study was supported by Fundação de Amparo à Pesquisa do Estado do Rio de Janeiro (FAPERJ) - Project Jovem Cientista do Nosso Estado and Conselho Nacional de Pesquisa e Desenvolvimento (CNPq). FBF holds a grant from $\mathrm{CNPq}$ for productivity in research.

\section{BIOETHICS AND BIOSSECURITY COMMITTEE APPROVAL}

The protocol for the collection of all clinical specimens and vaccination of animals was approved by the CEUA/IOC under no. L-45/2015, and for obtaining clinical samples from infected animals (necropsy) was approved by the CEUA/Fiocruz under no. LW 54/13.

\section{REFERENCES}

ABRANTES, T. R. et al. Identification of canine visceral leishmaniasis in a previously unaffected area by conventional diagnostic techniques and cell-block fixation. Revista do Instituto de Medicina Tropical de São Paulo, v.58, n.3, 2016.online.
Available from: < http://www.scielo.br/pdf/rimtsp/v58/0036-4665rimtsp-S1678-9946201658003.pdf > . Accessed: July 27, 2016. doi: 10.1590/S1678-9946201658003.

ALMEIDA, M. A. et al. Clinical and serological aspects of visceral leishmaniasis in northeast Brazilian dogs naturally infected with Leishmania chagasi. Veterinary Parasitology, v.127, n.3-4, p.227232, 2005. Available from: <http://www.sciencedirect.com/science/ article/pii/S0304401704004789>. Accessed: July 22, 2016. doi: 10.1016/j.vetpar.2004.10.010.

ALVES, A. S. et al. Evaluation of serological cross-reactivity between canine visceral leishmaniasis and natural infection by Trypanosoma caninum. Research in Veterinary Science, v.93, p.1329-1333, 2012. Available from: <http://ac.els-cdn.com/S0034528812002147/1-s2.0S0034528812002147-main.pdf? tid=84a2f542-9f91-11e6863400000a acb35d\&acdnat=1477935982_e-55b761a53ea1957acc592dc188ff6aa $>$. Accessed: Oct. 30, 2016. doi: 10.1016/j.rvsc.2012.07.006.

FRANCINO, O. et al. Advantages of real-time PCR assay for diagnosis and monitoring of canine leishmaniosis. Veterinary Parasitology, v.137, p.214-221, 2006. Available from: <http:// www.sciencedirect.com/science/article/pii/S0304401706000288>. Accessed: July 20, 2016. doi: 10.1016/j.vetpar.2006.01.011.

FERNANDES, C. B. Comparison of two commercial vaccines against visceral leishmaniasis in dogs from endemic areas: $\mathrm{IgG}$, and subclasses, parasitism, and parasite transmission by xenodiagnoses. Vaccine, v.32, p.1287-1295, 2014. Available from: <http://www. sciencedirect.com/science/article/pii/S0264410X13017891>. Accessed: July 05, 2016. doi: 10.1016/j.vaccine.2013.12.046.

MADEIRA, M. F. et al. Trypanosoma caninum n. sp. (Protozoa: Kinetoplastida) isolated from intact skin of a domestic dog (Canis familiaris) captured in Rio de Janeiro, Brazil. Parasitology, v.136, p.411423, 2009. Available from: <https://www.cambridge.org/core/journals/ parasitology/article/trypanosoma-caninum-n-sp-protozoa-kinetoplastidaisolated-from-intact-skin-of-a-domestic-dog-canis-familiaris-capturedin-rio-de-janeiro-brazil/EA3774601A09AD38F30FE7E478A32B6D>. Accessed: July 21, 2016. doi: 10.1017/S003118200900554X.

MARCONDES, M. et al. Longitudinal analysis of serological tests officially adopted by the Brazilian Ministry of Health for the diagnosis of canine visceral leishmaniasis in dogs vaccinated with leishmune. Veterinary Parasitology, v.197, p.649-652, 2013. Available from: $<$ http:// www.sciencedirect.com/science/article/pii/S0304401713003877>. Accessed: July 02, 2016. doi: 10.1016/j.vetpar.2013.07.013.

MINISTÉRIO DA SAÚDE. Manual de vigilância e controle da leishmaniose visceral. Brasília: Ministério da Saúde, 2006. Accessed: July 2016. Online. Availble from: <https://www.icict. fiocruz.br/sites/www.icict.fiocruz.br/files/Manual_Vigilancia_ Controle_Leishmaniose_Visceral.pdf $>$.

MINISTÉRIO DA SAÚDE. Brasil. Nota técnica conjunta $\mathrm{n}^{\circ}$ 01/2011- CGDT-CGLAB/DEVIT/SVS/MS. Esclarecimentos sobre substituição do protocolo diagnóstico da leishmaniose visceral canina (LVC). Brasília, 2011. Accessed: July 2016. Online. Available from: <http://www.dive.sc.gov.br/conteudos/zoonoses/ publicacoes/Guia_Basico_de_Orientacao_LVC_2015.pdf $>$.

MINISTÉRIO DA AGRICULTURA, PECUARIA E ABASTECIMENTO (MAPA). Nota técnica - MAPA - n 038/2014/ DFIP/DAS - suspensão da licença de fabricação e comercialização do produto Leishmune vacina contra leishamanoses visceral canina. Brasilia, 2014. Accessed: July 2016. Online. Available 
from: <http://www.agricultura.gov.br/arq_editor/file/Produtos $\% 20$ Veterin $\%$ C3\%A1rios/NOTA $\% 20$ TECNICA $\% 20$ DFIP\%203814\%20 LEISHMUNE.pdf $>$.

MINISTÉRIO DA SAÚDE e MINISTÉRIO DA AGRICULTURA, PECUARIA E ABASTECIMENTO. Nota de esclarecimento sobre as vacinas antileishmaniose visceral canina registrado no MAPA. Brasília, 2009. Accessed: July 2016. Online. Available from: $<$ http://www.agricultura.gov.br/arq_editor/file/Aniamal/Registros Atorizacoes/Produtos_veterinarios/Comunicacoes_e_instrucoes_ tecnicas/Nota_de_esclarecimento $\% 20$ sobre_a_vacina_.pdf $>$.

MINISTÉRIO DA SAÚDE. Nota técnica - Vacina AntiLeishmaniose Visceral Canina: Leishmune ${ }^{\circledR}$. 2005. Accessed: July 2016. Available from: <portal.saude.gov.br/gov/arquivos/pdf/ leishmune nota técnica.pdf>.

NOGUEIRA, F. S. et al. Leishmune ${ }^{\sqrt{1}}$ vaccine blocks the transmission of canine visceral leishmaniasis: Absence of Leishmania parasites in blood, skin and lymphnodes of vaccinated exposed dogs. Vaccine, v.23, p.4805-4810, 2005. Avilable from: $<$ http://www. sciencedirect.com/science/article/pii/S0264410X0500530X $>$. Accessed: July 27, 2016. doi: 10.1016/j.vaccine.2005.05.011.

PALATNICK-DE-SOUZA, C. B. Vaccines for leishmaniasis in the fore coming 25 years. Vaccine, v.26, n.14, p.1709-1724, 2008. Available from: <http://www.sciencedirect.com/science/article/pii/ S0264410X08000819>. Accessed: July 11, 2016. doi: 10.1016/j. vaccine.2008.01.023>.

RESENDE, D. M. et al. Epitope mapping and protective immunity elicited by adenovirus expressing the Leishmania amastigote specific
A2 antigen: Correlation with IFN-g and cytolytic activity by CD8+ T cells. Vaccine, v.26, p.4585-4593, 2008. Available from: $<$ http:// www.sciencedirect.com/science/article/pii/S0264410X08006932>. Accessed: July 21, 2016. doi: 10.1016/j.vaccine.2008.05.091.

SCHUBACH, E. Y. P. et al. Accuracy and reproducibility of a rapid chromatographic immunoassay for the diagnosis of canine visceral leishmaniasis in Brazil. Transactions of the Royal Society of Tropical Medicine and Hygiene, v.108, p.568-574, 2014. Available from: <http://www.ncbi.nlm.nih.gov/pubmed/25015665>. Accessed: July 10, 2016. doi: 10.1093/trstmh/tru109.

SILVA, D. A. et al. Geographical expansion of canine visceral leishmaniasis in Rio de Janeiro State, Brazil. Revista do Instituto de Medicina Tropical de São Paulo, v.57, n.5, p.435-438, 2015. Available from: <http://www.scielo.br/scielo.php?script=sci_arttex t\&pid $=$ S003646652015000500435\&lng=en\&nrm=iso\&tlng $=$ en $>$. Accessed: July 11, 2016. doi: 10.1590/S0036-46652015000500012.

SOLCÀ, M. S. et al. Comparação dos testes preconizados pelo ministério da saúde para o diagnóstico da leishmaniose visceral canina. In: CONGRESSO BRASILEIRO DE MEDICINA VETERINÁRIA, 40., 2013, Salvador, Ba. Available from: <http:// revistas.bvs-vet.org.br/recmvz/article/view/24900/25759>. Accessed: July 10, 2016.

TESTASICCA, M. C. S. et al. Antibody responses induced by Leish- $\mathrm{Tec}^{\circledR}$, an A2-based vaccine for visceral leishmaniasis, in a heterogeneous canine population. Veterinary Parasitology, v.204, p.169-176, 2014. Available from: <http://www.sciencedirect.com/ science/article/pii/S0304401714002349>. Accessed: July 02, 2016. doi: 10.1016/j.vetpar.2014.04.025. 